\title{
Article \\ Degradation of Decabromodiphenyl Ether in an Aerobic Clay Slurry Microcosm Using a Novel Immobilization Technique
}

\author{
Jung-Shan Hsu ${ }^{1,2}$, Ting-Yu Yu ${ }^{1}$, Da-Jiun Wei ${ }^{1}$, Wann-Neng Jane ${ }^{3}$ and Yi-Tang Chang ${ }^{1, * \mathbb{C}}$ \\ 1 Department of Microbiology, Soochow University, No.70 Linxi Rd., Shilin Dist., Taipei 11112, Taiwan; \\ rosalind@uab.edu (J.-S.H.); chowder0506@gmail.com (T.-Y.Y.); g11111155@gmail.com (D.-J.W.) \\ 2 Department of Pathology, University of Alabama at Birmingham, P210 West Pavilion 619 South 19th Street, \\ Birmingham, AL 35233-7331, USA \\ 3 Academia Sinica, Institute of Plant and Microbial Biology, 128 Sec. 2 Academia Rd., Nankang, \\ Taipei 11529, Taiwan; wnjane@gate.sinica.edu.tw \\ * Correspondence: ytchang@scu.edu.tw; Tel.: +886-2-2881-9471 (ext. 6862)
}

check for updates

Citation: Hsu, J.-S.; Yu, T.-Y.; Wei, D.-J.; Jane, W.-N.; Chang, Y.-T. Degradation of Decabromodiphenyl Ether in an Aerobic Clay Slurry Microcosm Using a Novel Immobilization Technique. Microorganisms 2022, 10, 402. https://doi.org/10.3390/ microorganisms10020402

Academic Editor: Giovanni Vallini

Received: 19 January 2022

Accepted: 7 February 2022

Published: 9 February 2022

Publisher's Note: MDPI stays neutral with regard to jurisdictional claims in published maps and institutional affiliations.

Copyright: (C) 2022 by the authors. Licensee MDPI, Basel, Switzerland. This article is an open access article distributed under the terms and conditions of the Creative Commons Attribution (CC BY) license (https:/ / creativecommons.org/licenses/by/ $4.0 /)$.

\begin{abstract}
A novel chitosan immobilization technique that entraps photocatalyst and microbes was developed and applied to decompose decabromodiphenyl ether (BDE-209) in a clay slurry microcosm. The optimized conditions for immobilization were obtained by mixing $1.2 \%(w / v)$ chitosan dissolved in $1 \%(v / v)$ acetic acid with nano- $\mathrm{TiO}_{2}$ particles and the BDE-209-degrading bacterial mixed culture. This aqueous mixture was injected into $1 \%(w / v)$ water solution containing sodium tripolyphosphate to form spherical immobilized beads. The surface of the immobilized beads was reinforced by $0.25 \%$ $(v / v)$ glutaraldehyde cross-linking. These beads had enough mechanical strength during BDE-209 degradation to maintain their shape in the system at a stirring rate of 200-rpm, while undergoing continuous $365 \mathrm{~nm}$ UVA irradiation. This novel $\mathrm{TiO}_{2}-\mathrm{Yi}-\mathrm{Li}$ immobilized chitosan beads system allowed a successful simultaneous integration of photolysis, photocatalysis and biodegradation to remove BDE-209. The remaining percentage of BDE-209 was $41 \%$ after 70 days of degradation using this system. The dominant bacteria in the BDE-209-degrading bacterial mixed culture during remediation were Chitinophaga spp., Methyloversatilis spp., Terrimonas spp. and Pseudomonas spp. These bacteria tolerated the long-term UVA irradiation and high-level free radicals present, while utilizing BDE-209 as their primary carbon resource. This new method has great potential for the treatment of a range of pollutants.
\end{abstract}

Keywords: chitosan immobilization; decabromodiphenyl ether; photolysis; photocatalysis; biodegradation

\section{Introduction}

Microbial bioremediation is considered to be an effective and environmentally friendly method for treating many emerging contaminants (ECs) present in soil and aquatic systems [1]. Polybrominated diphenyl ethers (PBDEs) have been identified as a class of ECs of great concern since they began to be used and they are still being used as brominated flame retardants in many industrial products worldwide. This means that their congeners are widely distributed in many environments [2]. For example, the concentration of PBDEs has been shown to be up to $37 \mathrm{mg} / \mathrm{kg}$ in soils sampled close to a PBDEs manufacturing factory in Jiangsu Province, People's Republic of China [3]. Furthermore, exposure to a high level of PBDEs has been shown to result in developmental neurotoxicity, reproductive system issues, liver carcinogenesis, and the chemicals can even be passed on to offspring via breast milk [4,5]. Therefore, the development of an efficient treatment system that is able to decrease the level of PBDEs in the environment is a critical issue. A previous study has demonstrated that various species of microbes, such as Pseudomonas spp., Terrimonas spp., Sphingomonas spp., Lysinibacillus spp., Bacillus spp. and Stenotrophomonas spp., have the ability to biodegrade PBDEs [6-8]. However, microbial bioremediation requires a longer 
treatment time compared with chemical oxidation remediation or a modified bioremediation process $[9,10]$. To improve the efficiency of PBDEs biodegradation, one possibility is to combine various eco-friendly physical/chemical/biological processes [10-12].

The photocatalyst titanium dioxide $\left(\mathrm{TiO}_{2}\right)$ has been shown to have a strong ability to accelerate photodegradation of ECs, including BDE-209 $\left(\mathrm{C}_{12} \mathrm{Br}_{10} \mathrm{O}\right)$, in aquatic systems when accompanied by UV irradiation [13]. One of the major limitations that have been reported is the aggregation of $\mathrm{TiO}_{2}$ nanoparticles, which significantly reduces the effectiveness of the photocatalytic reaction [14]. Efficiencies of ECs removal are then restricted by the weaker photocatalytic reaction due to a low UV light irradiation energy density; this is particularly a problem in a complex environmental matrix such as a soil slurry system. Moreover, to separate nano sized $\mathrm{TiO}_{2}$ by simple filtration after treatment is challenging due to their very small size; this limits the ability to reuse these particles [14,15]. In recent years, various techniques have been developed for immobilizing $\mathrm{TiO}_{2}$ using organic or inorganic materials, and these have included silica gel, films, membranes, concrete, glass, alginate beads and chitosan beads. The use of an immobilization process before treating the ECs makes it a relatively easy process to recover the $\mathrm{TiO}_{2}$ nanoparticles once treatment is completed [16-22].

There is little information available on the immobilization of a photocatalyst and microbes together within a single matrix at the same time and then the use of these beads to treat ECs ex situ. In order to combine microbial bioremediation with photocatalytic degradation after immobilization, the microbes and the $\mathrm{TiO}_{2}$ need to be entrapped simultaneously. The aim of this study is to utilize the chitosan-entrapped immobilization technique to develop an efficient removal system for remediating BDE-209 in a soil slurry system by combining photolysis, photocatalytic reactions and microbial degradation. The characteristics of the $\mathrm{TiO}_{2}$-microbes immobilized chitosan beads were assessed in this study, including the optimal chemical composition of the immobilization procedure; the microscopic surface of the beads; bacterial viability of the beads; bacterial entrapment and releasing ability of the beads. By analyzing BDE-209 removal in this system and pinpointing the changes that occur within the bacterial community during remediation, it is possible to evaluate the usefulness of the $\mathrm{TiO}_{2}$-microbes immobilized chitosan bead system for the biodegradation of BDE-209 present in a soil slurry.

\section{Materials and Methods}

\subsection{Chemicals, Soil and Microorganisms}

High-molecular-weight Chitosan (Sigma-Aldrich ${ }^{\circledR}$, Iceland) was selected as the immobilization matrix material. The $\mathrm{TiO}_{2}$-nanoparticles (P25) were manufactured by Uni Region Bio-Tech Inc., Taipei, Taiwan. The BDE-209 (Alfa Aesar, Karlsruhe, Germany) used in this study had a purity above $99 \%$. All other chemicals, including acetic acid, sodium tripolyphosphate $\left(\mathrm{Na}_{5} \mathrm{O}_{3} \mathrm{P}_{10}\right)$, methyl blue (MB), and others, were reagent grade with a purity of $>99 \%$. All organic liquids, for example glutaraldehyde, were of HPLC grade with a purity of $>99.9 \%$. The Milli-Q water $(>18 \mathrm{M} \Omega \mathrm{cm})$ used in this study was obtained from a Millipore water purification system.

Pure Ca-montmorillonite was used as the clay slurry microcosm in this study, and this was purchased from the Clay Minerals Society, Purdue University, Indiana, USA. This clay was used to eliminate the confounding influence of soil organic matter (SOM), which is present in surface soils, and to a much lesser extent in subsoils, on UV photolysis and biodegradation. The physical-chemical characteristics of the sorbents are shown in Table 1. 
Table 1. Physical-chemical characteristics of the clay used in this study ${ }^{1}$.

\begin{tabular}{|c|c|c|c|c|c|}
\hline $\begin{array}{c}\text { Clay } \\
\text { (Abbreviation) }\end{array}$ & $\begin{array}{c}\text { Chemical Composition }{ }^{1} \\
(\%)\end{array}$ & Source & $\begin{array}{l}\left.\text { BET-(N } N_{2}\right) \\
\operatorname{SA}\left(\mathrm{m}^{2} / \mathrm{g}\right)\end{array}$ & $\begin{array}{c}\text { SOM } \\
(\%)\end{array}$ & $\begin{array}{c}\text { CEC } \\
(\mathrm{meq} / 100)\end{array}$ \\
\hline $\begin{array}{c}\text { Texas } \\
\text { Montmorillonite } \\
\text { STx-1 }\end{array}$ & $\begin{array}{c}\mathrm{SiO}_{2}: 70.1, \mathrm{Al}_{2} \mathrm{O}_{3}: 16.0, \mathrm{TiO}_{2}: 0.22 \\
\mathrm{Fe}_{2} \mathrm{O}_{3}: 0.65, \mathrm{FeO}: 0.15, \mathrm{MnO}_{0}: 0.009 \\
\mathrm{MgO}: 3.69, \mathrm{CaO}: 1.59, \mathrm{Na}_{2} \mathrm{O}: 0.27 \\
\mathrm{~K}_{2} \mathrm{O}: 0.078, \mathrm{~F}: 0.084, \mathrm{P}_{2} \mathrm{O}_{5}: 0.026 \\
\mathrm{~S}: 0.04\end{array}$ & $\begin{array}{l}\text { Gonzales County, } \\
\text { TX, USA }\end{array}$ & 83.79 & 0 & 84.4 \\
\hline
\end{tabular}

${ }^{1}$ : based on the website http://www.clays.org/sourceclays_data.html (accessed on 17 January 2022).

The isolations of the indigenous bacterial mixed cultures used in this study were from PBDEs-contaminated river sediment and were carried out by our laboratory was described in a previous study [6]. The ability to remove BDE-209 by the Yi-Li and Ta-An bacterial mixed cultures has been shown previously to result in about $60 \%$ biodegradation of BDE-209 at initial concentration $25 \mathrm{mg} / \mathrm{kg}$ over 6 months when BDE-209 was the sole carbon source in a soil slurry microcosm [23]. The two mixed cultures were used to provide the bacteria within the two types of novel $\mathrm{TiO}_{2}$-microbes immobilization beads. These two types of novel beads thus ought to be able to utilize PBDEs as a sole carbon source and the bacteria within them should also be capable of growing well under long-term UVA irradiation [6].

\subsection{Experimental Procedure}

\subsubsection{Preparation of the $\mathrm{TiO}_{2}-\mathrm{Yi}-\mathrm{Li}$ Immobilized Chitosan Beads}

The scheme used in this study to create the $\mathrm{TiO}_{2}$ immobilized chitosan beads is shown in Figure S1. In total, $40 \mathrm{~mL}$ of Yi-Li bacterial mixed culture was concentrated into $2 \mathrm{~mL}$ by centrifugation and then $1 . \mathrm{mL}$ was added to and mixed with the $\mathrm{TiO}_{2}$-chitosan suspension. The rest of the immobilization procedure was the same as the procedure used for creating the $\mathrm{TiO}_{2}$ immobilized chitosan beads. The whole procedure was carried out under aseptic conditions.

\subsubsection{Bacterial Viability Assay of $\mathrm{TiO}_{2}-\mathrm{Yi}$-Li Immobilized Chitosan Beads}

First, $20 \mathrm{~mL}$ Yi-Li bacterial mixed culture were aliquoted and centrifuged at $3000 \mathrm{rpm}$ for $5 \mathrm{~min}$ to remove the soil from the original culture. The supernatant was then transferred to a new tube and centrifuged at 10,000 rpm for $10 \mathrm{~min}$. The pellet was resuspended in $1 \mathrm{~mL} 0.85 \% \mathrm{NaCl}$ and added to each reagent for the designated time period and under the designated conditions as shown in Table 2.

Table 2. Details of the experimental conditions set up for the MB degradation experiments using different concentration of $\mathrm{TiO}_{2}$ immobilized chitosan beads.

\begin{tabular}{cccc}
\hline Variants & Light $^{\mathbf{1}}$ & Beads & Type of Beads \\
\hline 1 & UV & No & \\
2 & Dark & No & chitosan beads \\
3 & UV & Yes & chitosan beads \\
4 & Dark & Yes & $0.05 \% \mathrm{TiO}_{2}$ immobilized chitosan beads \\
5 & Dark & Yes & $0.01 \% \mathrm{TiO}_{2}$ immobilized chitosan beads \\
6 & UV & Yes & $0.05 \% \mathrm{TiO}_{2}$ immobilized chitosan beads \\
7 & UV & Yes & $0.10 \% \mathrm{TiO}_{2}$ immobilized chitosan beads \\
8 & UV & Yes
\end{tabular}

${ }^{1}$ The UV light source used in this study was a $365 \mathrm{~nm}$ LED UVA light source set at $2-2.4 \mathrm{~mW} / \mathrm{cm}^{2}$.

After serial dilution of the samples, $100 \mu \mathrm{L}$ of each dilution was spread onto: (1) R2A agar for enumeration of soil heterotrophic bacteria; (2) BDE-209-mineral salts basal agar (BDE209-MSA) for the enumeration of BDE-209-biodegrading bacteria. After incubation, the colonies were counted and the bacteria numbers in the original sample were calculated. 
2.2.3. Degradation of Aqueous $\mathrm{MB}$ by the Photocatalytic Activity of $\mathrm{TiO}_{2} \mathrm{Immobilized}$ Chitosan Beads

The aqueous MB (initial concentration is set up at $20 \mathrm{mg} / \mathrm{L}$ ) degradation experiment was set up in order to evaluate the photocatalytic activity of $\mathrm{TiO}_{2}$ immobilized chitosan beads. Table 3 shows the detailed design of the experimental conditions for MB degradation. The degradation of $\mathrm{MB}$ using $0.01 \%, 0.05 \%$ or $0.1 \% \mathrm{TiO}_{2}$ immobilized chitosan beads under continuing $365 \mathrm{~nm}$ UVA irradiation for $24 \mathrm{~h}$. The optimal proportion of $10 \%(w / v) \mathrm{TiO}_{2}$ immobilized chitosan beads was added and were shaken at $100 \mathrm{rpm}$ at room temperature under various experimental conditions.

Table 3. Details of the viability assay used on the Yi-Li Bacteria, including the various chemicals used during the immobilization procedure.

\begin{tabular}{cccc}
\hline Step & Chemicals & UV & Contacting Time \\
\hline 1 & Control- $0.85 \% \mathrm{NaCl}$ & No & Immediately \\
2 & $1 \%$ acetic acid & No & Immediately \\
3 & $0.1 \% \mathrm{TiO}_{2}$ in $1 \%$ acetic acid & No & Immediately \\
4 & $0.05 \% \mathrm{TiO}_{2}$ in $1 \%$ acetic acid & No & Immediately \\
5 & $1 \%$ sodium tripolyphosphate & No & Immediately \\
6 & $0.25 \%$ glutaraldehyde & No & Immediately \\
7 & $1.2 \%$ chitosan dissolved in $1 \%$ acetic acid & No & 30 min. \\
8 & $1.2 \%$ chitosan dissolved in $1 \%$ acetic acid & No & $3 \mathrm{~h}$. \\
\hline 9 & Control-0.85\% NaCl & Yes & 3 min. \\
10 & $1 \%$ acetic acid & Yes & 3 min. \\
11 & Chitosan- $0.1 \% \mathrm{TiO}_{2}$ mixed suspension & Yes & 3 min. \\
12 & Chitosan- $0.05 \% \mathrm{TiO}_{2}$ mixed suspension & Yes & 3 min. \\
13 & Chitosan- $0.01 \% \mathrm{TiO}_{2}$ mixed suspension & Yes & 3 min. \\
\hline
\end{tabular}

2.2.4. Bacterial Entrapment and Release Ability Assay of the $\mathrm{TiO}_{2}-\mathrm{Yi}-\mathrm{Li}$ Immobilized Chitosan Beads

The same protocol, as described in Section 2.2.2, was performed on the $\mathrm{TiO}_{2}-\mathrm{Yi}-\mathrm{Li}$ immobilized chitosan beads. Specifically, $100 \mu \mathrm{L}$ of solution from each step, as showed in Figure 1, was used and plated as described. After incubation, the colonies were counted and bacteria numbers in the original sample calculated.

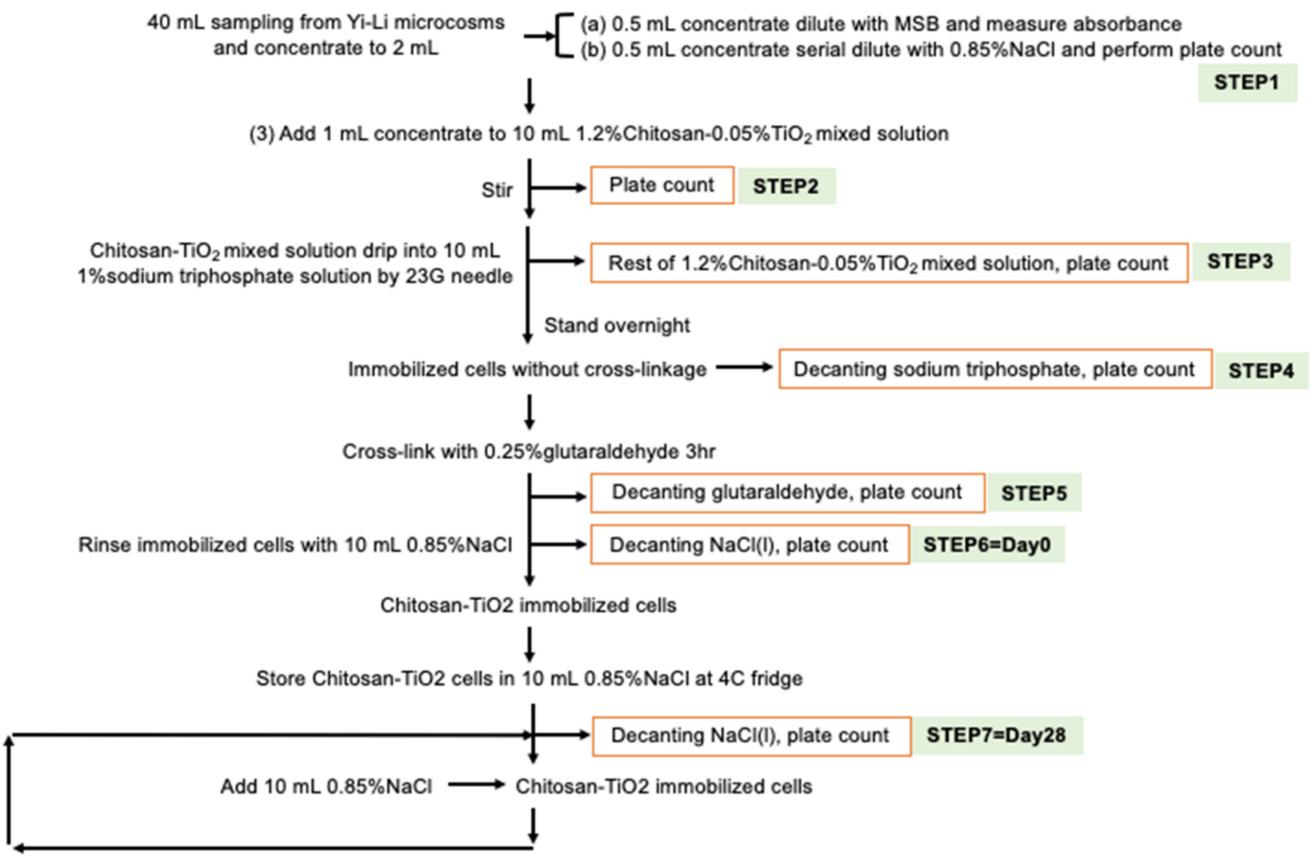

Figure 1. Immobilization Procedure used to Create the $\mathrm{TiO}_{2}-\mathrm{Yi}-\mathrm{Li}$ Immobilized Beads. 
2.2.5. Degradation of BDE-209 in a Clay Slurry Microcosm by the $\mathrm{TiO}_{2}$-Yi-Li Immobilized Chitosan Beads

BDE-209-contaminated clay were initially prepared at $20 \mathrm{mg} / \mathrm{kg}$, as described in a previous study [24]. Batch biodegradation experiments used the BDE-209 $(20 \mathrm{mg} / \mathrm{kg})$ as the sole carbon source and were performed in an aerobic clay slurry microcosm system. The ratio of clay to mineral salts basal medium (MSB) was 2:25 $(\mathrm{g} / \mathrm{mL})$. The clay slurries were sterilized, and this was confirmed by spread plates. At the beginning of the experiments, the optimal proportion of $10 \%(w / v) \mathrm{TiO}_{2}-\mathrm{Yi}$-Li immobilized chitosan beads was added to the clay slurry microcosms (data not shown). The clay slurry microcosms were incubated with shaking at $100 \mathrm{rpm}$ at room temperature under various experimental conditions. These were: (1) biodegradation alone by $\mathrm{TiO}_{2}-\mathrm{Yi}-\mathrm{Li}$ bacteria immobilized cells; (2) photodegradation alone by the $365 \mathrm{~nm}$ LED UVA irradiation at $2.0-2.4 \mathrm{~mW} / \mathrm{cm}^{2}$; (3) both biodegradation and photodegradation; (4) the negative control microcosms were sterilized with the biocide $\mathrm{NaN}_{3}(\mathrm{ca} 1.0 \%, w / v)$. Samples for the experimental analysis were taken from each individual microcosm.

\subsection{Analytical Methods}

\subsubsection{Analyses with a Scanning Electron Microscope}

A cryogenic scanning electron microscope (SEM, FEI Quanta 200/Quorum PP2000TR FEI, Plant Cell Biology Core Laboratory, The Institute of Plant and Microbial Biology, Academia Sinica, Taiwan) was used to carry out the observations of the immobilized cell samples at $5 \mathrm{kV}$. The beads containing the immobilized cells were initially cut by scalpel and then they were fixed on a specimens-stage using TedPella PELCO ${ }^{\circledR}$ conductive graphite gel. Next the specimens were pretreated with a sequence of freeze-dried and Au sputtering processes. Following this procedure, the specimens were frozen using a manifold freeze dryer and then are dried at $-80^{\circ} \mathrm{C}$ overnight. Finally, energy dispersive X-ray (EDX) analysis on immobilized cell samples was performed by the field emission-SEM using a EDX spectrometer (Hitachi S-4700 type-II with Horiba EMAX-ENERGY EX-300, National Tsing Hua University, Hsinchu, Taiwan).

\subsubsection{BDE-209 Analysis}

A serial process involving ultrasound-assisted extraction, solid-phase extraction, and vacuum concentration was carried out on the clay slurry microcosm samples. After this pretreatment, the samples underwent HPLC analysis to detect and measure BDE-209. The HPLC system was equipped with a UV detector (YL-9100, Young-Lin, South Korea) at $226 \mathrm{~nm}$, an ODS Hypersil C18 column $(250 \mathrm{~mm} \times 4.6 \mathrm{~mm}$, Thermo Scientific, Waltham, MA, USA) and was operated at $30^{\circ} \mathrm{C}$. The operating conditions of the HPLC system were as follows: $25 \mu \mathrm{L}$ injection sample and $1 \mathrm{~mL} / \mathrm{min}$ mobile phase $100 \%$ acetonitrile. Triplicate analysis of the BDE-209 in each sample was carried out. The retention time of BDE-209 on this HPLC chromatographic system was $8.916 \mathrm{~min}$.

\subsubsection{Bromide Analysis}

Bromide $\left(\mathrm{Br}^{-}\right)$byproduct concentrations were measured at intervals during debromination as the BDE-209 degradation in a clay slurry microcosm by $\mathrm{TiO}_{2}-\mathrm{Yi}-\mathrm{Li}$ immobilized beads took place. This was carried out using an ion chromatograph (IC, Metrohm 883/863, Switzerland) equipped with a conductivity detector. Samples of the supernatant liquid were separated by high-speed centrifugation, filtered through a $0.22-\mu \mathrm{m}$ nylon filter, and then their $\mathrm{Br}^{-}$concentration was measured immediately. The retention time for $\mathrm{Br}^{-}$by IC chromatography was 8.29 min.

\subsubsection{Bacterial Count Analysis}

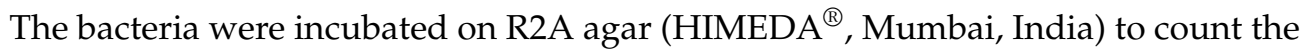
total number of heterotrophic bacteria able to grow on this medium. Restrictive BDE209MSA agar was also used to count the bacteria identified in this system. Each sample was 
diluted $10^{1}-10^{10}$-fold using sterilized saline solution $\left(\mathrm{KH}_{2} \mathrm{PO}_{4}\right.$ and $\left.\mathrm{MgCl}_{2} 6 \mathrm{H}_{2} \mathrm{O}\right)$ after the sample had been collected; then, $0.2 \mathrm{~mL}$ of each dilution was spread on the relevant agar plates and incubated at room temperature for up to $48 \mathrm{~h}$.

\subsubsection{Bacterial Community Analysis}

Bacterial community analysis was applied to assess the changes in the bacterial community during the BDE-209 degradation. At two time points, day 0 (D0) and day 56 (D56). DNA samples were extracted using a Soil Genomic DNA Purification Kit (GeneMark, Taipei, Taiwan). The bacterial communities were then analyzed using the MiSeq, paired-end $300 \mathrm{bp}$ primer set [25], which amplifies the V3-V4 domains of 16S rDNA of the bacteria on an Illumina 454 (Biotools, Taipei, Taiwan). The DNA sequences present in the amplified samples were processed into an amplicon library and this was followed by sequencing using synthesis sequencing. Finally, after the results were subjected to cluster generation, the bacterial communities present in the samples during the BDE-209 biodegradation were investigated.

\subsubsection{MB Analysis}

Absorbance measurements were carried out on a spectrophotometer and degradation of $\mathrm{MB}$ at a wavelength of $664 \mathrm{~nm}$ was measured.

\section{Results}

\subsection{Characteristics of the $\mathrm{TiO}_{2}-\mathrm{Yi}$-Li Immobilized Chitosan Beads}

3.1.1. Determination of the Chemical Concentrations to Be Used in the Immobilization Procedure

In order to determine the optimal concentrations of chitosan, sodium tripolyphosphate, and glutaraldehyde to be used in the immobilization procedure, preliminary tests were carried out under the conditions shown in Table 4.

Table 4. The total weight of the regular-shaped immobilized beads manufactured using various concentration of $\mathrm{TiO}_{2}$-chitosan suspension and sodium tripolyphosphate.

\begin{tabular}{|c|c|c|c|c|}
\hline Batch & Chitosan $(w / v)^{1}$ & $\begin{array}{c}\text { Sodium Tripolyphosphate } \\
(w / v)\end{array}$ & $\begin{array}{c}\text { Glutaraldehyde } \\
(v / v)\end{array}$ & $\begin{array}{c}\text { Weight of Immobilized } \\
\text { Cells (g) }{ }^{2}\end{array}$ \\
\hline 1 & $2.0 \%$ & $3 \%$ & $0.25 \%$ & $\mathrm{NA}^{3}$ \\
\hline 2 & $3.0 \%$ & $3 \%$ & $0.25 \%$ & $\mathrm{NA}^{3}$ \\
\hline 3 & $3.5 \%$ & $3 \%$ & $0.25 \%$ & $\mathrm{NA}^{3}$ \\
\hline 4 & $4.0 \%$ & $3 \%$ & $0.25 \%$ & 4.6 \\
\hline 5 & $4.5 \%$ & $3 \%$ & $0.25 \%$ & 5.5 \\
\hline 6 & $1.2 \%$ & $1 \%$ & $0.25 \%$ & 12.5 \\
\hline
\end{tabular}

${ }^{1}$ : Chitosan dissolved in $1 \%$ acetic acid, ${ }^{2}$ : Generated, ${ }^{3}$ : Not available for regular-shaped immobilized beads.

Six batches of $\mathrm{TiO}_{2}$ immobilized chitosan beads were made using different concentrations of reagents. The total weight and the appearance of the $\mathrm{TiO}_{2}$ immobilized chitosan beads made from $50 \mathrm{~mL}$ of chitosan- $\mathrm{TiO}_{2}$ mixed suspension were the two factors used to determine the optimal concentrations of each reagent needed for the immobilization procedure. Previous studies suggested that the concentration of chitosan in the solution should be in the range between $1.2 \%$ to $4.5 \%$ and that gelling would require the addition of an aqueous solution of tripolyphosphate at a concentration within the range between $1 \%$ and 3\%; finally, to reinforce the surface of beads, glutaraldehyde at a concentration of $0.25 \%$ would be needed in order to obtain regular shaped beads that have good protection against environmental shear forces [26-28]. Batches one, two and three failed to form regular shaped beads, batches four and five did result in enough spherical beads, but the diameters of the beads were not consistent. In the end, batch six gave the best $\mathrm{TiO}_{2}$ immobilized chitosan beads and the condition used for this batch were: $1.2 \%(w / v)$ chitosan mixed

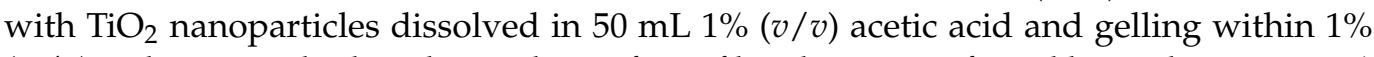
$(w / v)$ sodium tripolyphosphate. The surface of beads was reinforced by soaking in $0.25 \%$ 
glutaraldehyde $(v / v)$. In total, $12.5 \mathrm{~g} \mathrm{TiO}_{2}$ of immobilized chitosan beads were able to be produced, and these had an average diameter of $2 \mathrm{~mm}$.

3.1.2. Viability of the BDE-209-Degrading Microorganisms That Have Been Immobilized in the Chitosan Beads

The bacteria viability test was set up to confirm that the BDE-209-degrading bacterial mixed culture is able to survive in contact with the various reagents used in immobilization process before degradation of $\mathrm{BDE}-209$ by $\mathrm{TiO}_{2}-\mathrm{Yi}$ - $\mathrm{Li}$ immobilized chitosan beads in an aerobic clay slurry microcosm; this is because chitosan, glutaraldehyde and $\mathrm{TiO}_{2}$ have all been reported to have antibacterial ability $[24,29,30]$. In this set of tests, two different BDE-209-degrading bacterial mixed cultures were used, Yi-Li and Da-An, to create the beads [6]. The results of the Yi-LI bacteria viability test are presented in Figure 2.

(a)

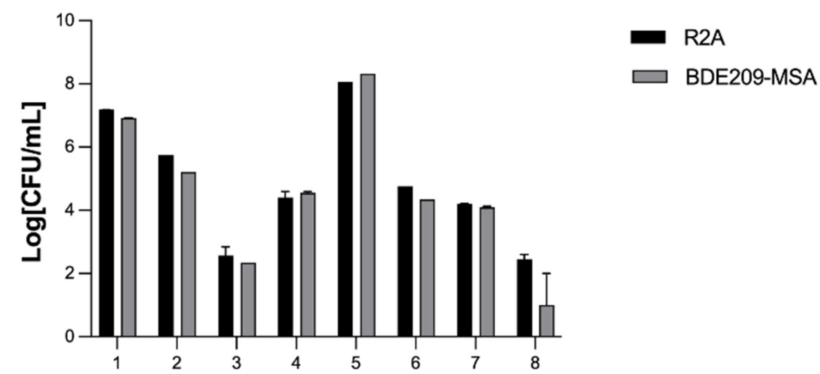

(b)

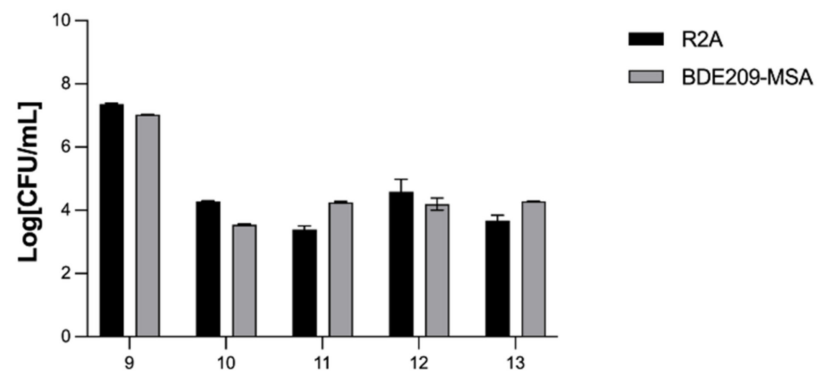

Figure 2. The viability of the Yi-Li bacteria in various chemicals used during the immobilization procedure. (a) Yi-Li bacteria viability (b) Yi-Li bacteria viability under UV irradiation. Value 1-13 on the $\mathrm{X}$ axis is defined as each step of Table 2, including the various chemicals used during the immobilization procedure. Step: 1: Control- $0.85 \% \mathrm{NaCl}$; step 2: $1 \%$ acetic acid; step 3: $0.1 \% \mathrm{TiO}_{2}$ in $1 \%$ acetic acid; step 4: $0.05 \% \mathrm{TiO}_{2}$ in $1 \%$ acetic acid; step 5: $1 \%$ sodium triphosphate; step 6: $0.25 \%$ glutaraldehyde; step 7: 1.2\% chitosan dissolved in 1\% acetic acid; step 8: $1.2 \%$ chitosan dissolved in $1 \%$ acetic acid; step 9: Control- $0.85 \% \mathrm{NaCl}$; step 10: $1 \%$ acetic acid; step 11: Chitosan- $0.1 \% \mathrm{TiO}_{2}$ mixed suspension; step 12: Chitosan- $0.05 \% \mathrm{TiO}_{2}$ mixed suspension; step 13: Chitosan- $0.01 \% \mathrm{TiO}_{2}$ mixed suspension.

The number of viable Yi-Li bacteria were found to decrease when they were in contact with chitosan, $\mathrm{TiO}_{2}$ and glutaraldehyde. Nonetheless, the Yi-Li bacteria were able to survive all of the chemical reagent steps used in the immobilization procedure and seem to be quite resistant to the level of free radicals released by the $\mathrm{TiO}_{2}$ under continuous $365 \mathrm{~nm}$ UVA irradiation. As Figure S2 shows, the Da-An bacteria were killed by $0.25 \%$ glutaraldehyde and the viable Da-An bacteria were not present beyond this point. Therefore, the Yi-Li bacteria, and not the Da-An bacteria, was selected to be immobilized in the chitosan beads for the remaining experiments.

The bacterial entrapment and releasing ability of the $\mathrm{TiO}_{2}-\mathrm{Yi}$ - $\mathrm{Li}$ immobilized beads are shown in Figure 3.

The purpose of this experiment was to indirectly confirm that the immobilization technique was able to entrap the bacteria within the chitosan beads and then slowly release the bacteria from the immobilized beads into the environment. Step 1 found that the initial bacterial number added to the $\mathrm{TiO}_{2}$-chitosan mixed suspension was $1.31 \times 10^{8} \mathrm{CFU} / \mathrm{mL}$. Step 2 shows the remaining bacteria after mixing the bacteria with the $\mathrm{TiO}_{2}$-chitosan mixed suspension. Step 3 shows the number of remaining bacteria, $2.96 \times 10^{5} \mathrm{CFU} / \mathrm{mL}$, after contact for $30 \mathrm{~min}$ with the $\mathrm{TiO}_{2}$-chitosan mixed suspension. The bacteria numbers slightly dropped during Step 2 and Step 3 since both chitosan and $\mathrm{TiO}_{2}$ have an antibacterial effect. At Step 4, there was no bacteria present in the decanted sodium tripolyphosphate solution, which indicates that all of the added bacteria were entrapped within the chitosan immobilized beads. At Steps 5 and 6, no bacterial were detected in the decanted glutaraldehyde 
and $\mathrm{NaCl}$, which confirms that the bacteria were still immobilized within the chitosan beads without leakage. At Step 7, which was carried out 28 days after beads had been made, the number of bacteria released into aqueous solution was estimated to be $8.9 \times 10^{8} \mathrm{CFU} / \mathrm{mL}$, which is more than the initial number of Yi-Li bacteria added during the immobilization process. The bacterial release profile was carried out in an aqueous solution; yet, bacteria entrapped in the beads, once released, can recover and thrive under such conditions, although no nutrients are available in the aqueous solution. Thus, it would seem that the Yi-Li bacteria were able to recover from the immobilization process, divide and finally become released from the chitosan immobilized beads into the outside environment.

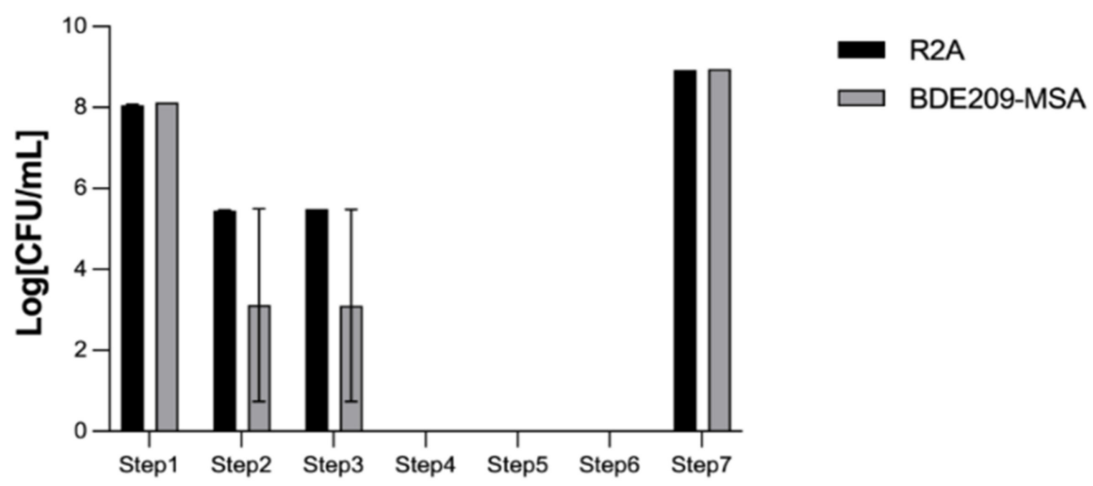

Figure 3. The bacterial entrapment and release ability of $\mathrm{TiO}_{2}-\mathrm{Yi}-\mathrm{Li}$ immobilized chitosan beads. Value on the $\mathrm{X}$ axis is defined as each step of Table 3.

3.1.3. The SEM Microphotographs and EDX Profile of the $\mathrm{TiO}_{2}$ Immobilized Chitosan Beads

The SEM microphotographs of the $\mathrm{TiO}_{2}$ immobilized chitosan beads and the $\mathrm{TiO}_{2}-$ Yi-Li immobilized chitosan beads are shown in Figure 4. EDX analysis of the $\mathrm{TiO}_{2}-\mathrm{Yi}-\mathrm{Li}$ immobilized chitosan beads is shown in Figure 5. The aggregated $\mathrm{TiO}_{2}$ can be observed in Figure 4 on the surface of the bead (a), (b), and (c) at different magnifications. The rodshaped or circle shaped subject labeled in Figure 4. (d) with red arrow would seem to be a bacillus or coccoid form bacterium.

\subsection{Degradation of BDE-209 by $\mathrm{TiO}_{2}-\mathrm{Yi}$-Li Immobilized Chitosan Beads in an Aerobic Clay Slurry Microcosm}

\subsubsection{BDE-209 Degradation}

To confirm ability of the $\mathrm{TiO}_{2}-\mathrm{Yi}$-Li immobilized chitosan beads to remove BDE-209 in a clay slurry microcosm and also to determine the contribution to this process of the Yi-Li bacteria and the $\mathrm{TiO}_{2}$, a clay slurry microcosm containing BDE-209 was set up. The $\mathrm{TiO}_{2}{ }^{-}$ Yi-Li immobilized chitosan beads or Yi-Li immobilized chitosan beads were added the slurry systems and UVA irradiation begun; this time point was recorded as Day 0 (D0). The concentration of BDE-209 remaining in the clay slurry on Day 0 (D0), Day 42 (D42) and Day 70 (D70) were measured and are shown in Figure 6.

The initial concentration of BDE-209 for both systems on D0 were $20 \mathrm{mg} / \mathrm{kg}$. The BDE209 concentration of the system containing the $\mathrm{TiO}_{2}-\mathrm{Yi}-\mathrm{Li}$ immobilized chitosan beads had decreased to $13.81 \mathrm{mg} / \mathrm{kg}$ on D42 and to $8.22 \mathrm{mg} / \mathrm{kg}$ on D70. The remaining ratio of BDE-209 was calculated for this system to be 0.41 after 70 days of degradation. The BDE-209 concentration of the system containing the Yi-Li immobilized chitosan beads was found to have decreased to $14.93 \mathrm{mg} / \mathrm{kg}$ on D42 and to $10.69 \mathrm{mg} / \mathrm{kg}$ on D70. The remaining ratio of BDE-209 was calculated to be 0.53 .

Debromination of BDE-209 has been reported to occur by biodegradation and by photolysis. The amount of bromide released into the clay soil slurry was measured for both systems in order to assess the debromination of BDE-209. The $\mathrm{TiO}_{2}$-Yi-Li immobilized chitosan beads with UVA irradiation showed a higher BDE-209 degradation ability than adding the beads containing Yi-Li bacteria alone. The $\mathrm{TiO}_{2}-\mathrm{Yi}-\mathrm{Li}$ immobilized chitosan 
beads with $365 \mathrm{~nm}$ UVA irradiation produced bromide concentrations that increased from $0.64 \mathrm{mg} / \mathrm{L}$ on D0 to $27.69 \mathrm{mg} / \mathrm{L}$ on D70. On the other hand, the Yi-Li immobilized chitosan beads with UVA irradiation produce bromide concentrations that increased from $1.19 \mathrm{mg} / \mathrm{L}$ on D0 to $22.95 \mathrm{mg} / \mathrm{L}$ on D70.

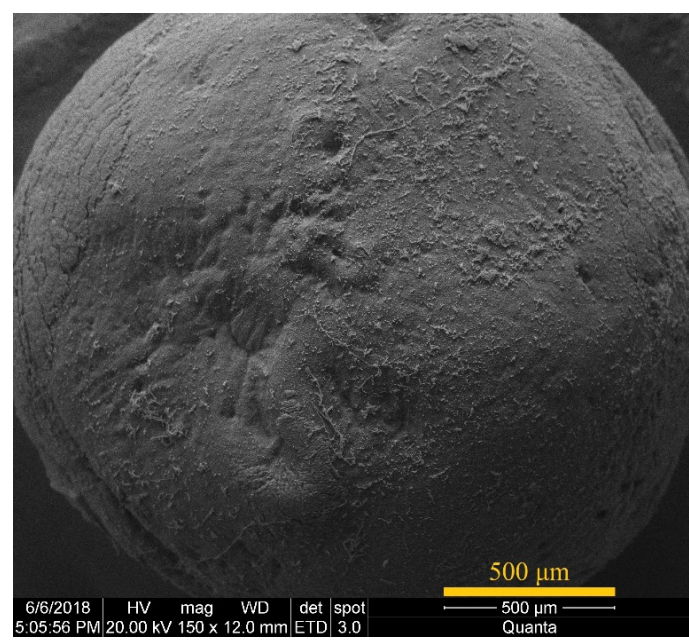

(a)

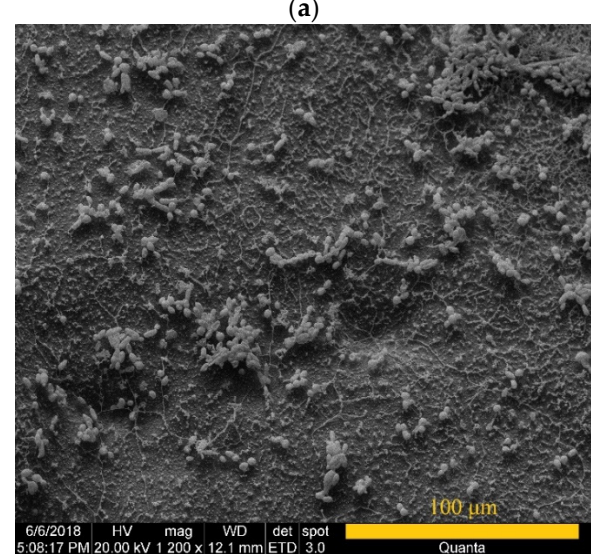

(c)

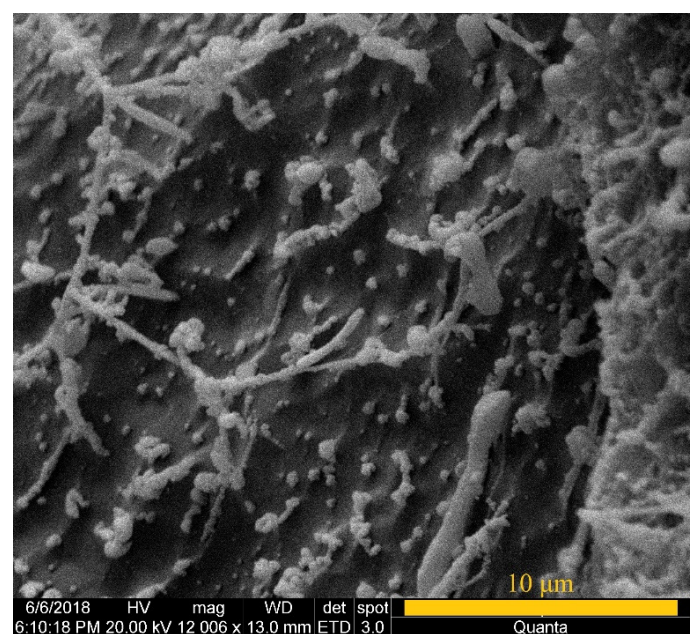

(b)

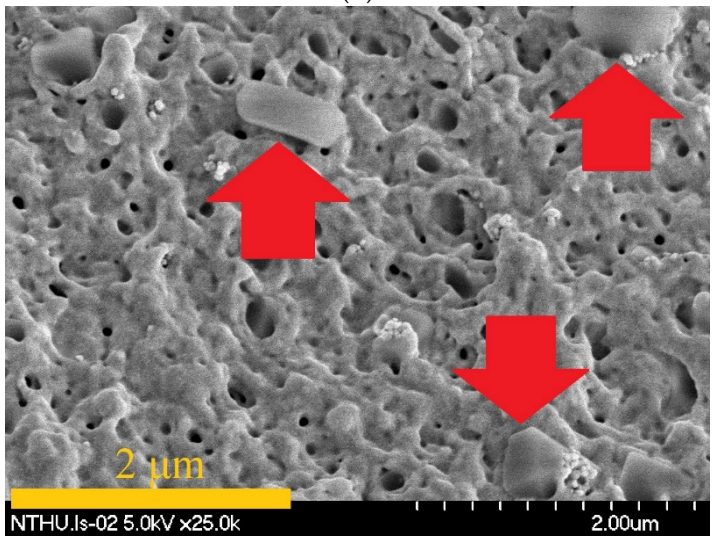

(d)

Figure 4. SEM microphotographs of the surface of the beads. They are magnified by (a) $\times 150$ and the cross-section magnified by (b) $\times 1200$ of $\mathrm{TiO}_{2}$ immobilized chitosan beads and (c) $\times 12,006$ and (d) $\times 25,000$. Length scale consist of an orange bar. Bacteria marked by red arrows.

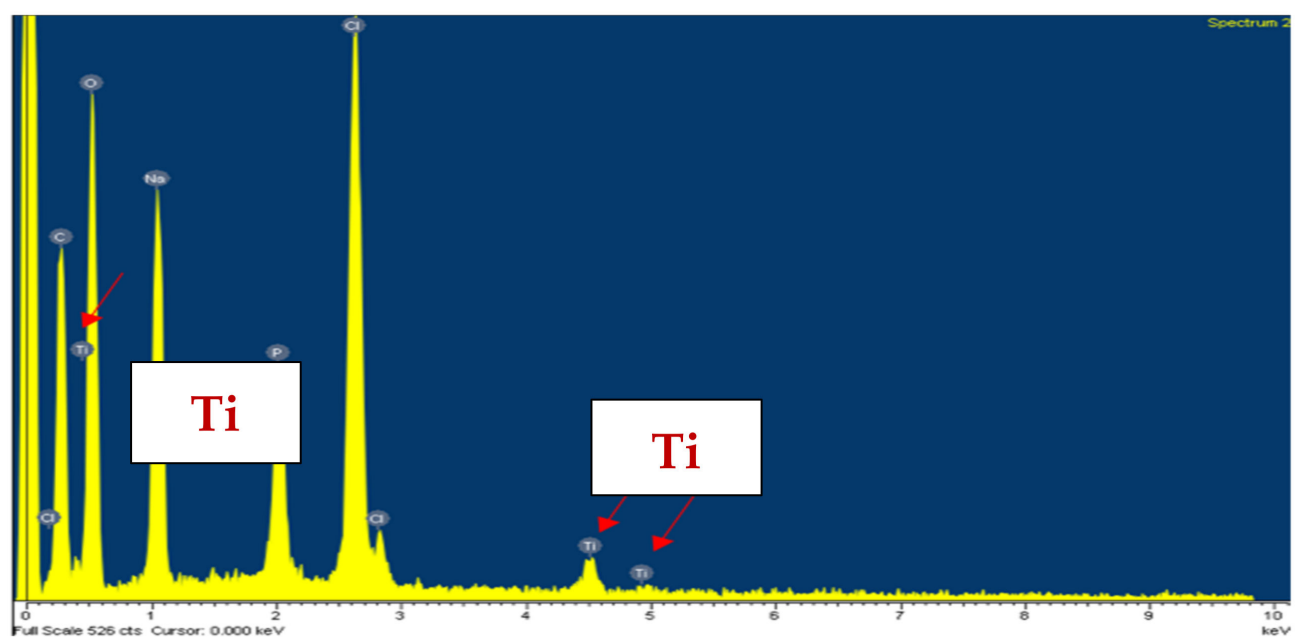

Figure 5. EDX analysis of the $\mathrm{TiO}_{2}-\mathrm{Yi}-\mathrm{Li}$ immobilized chitosan beads. Signs of Ti marked by red arrows. 


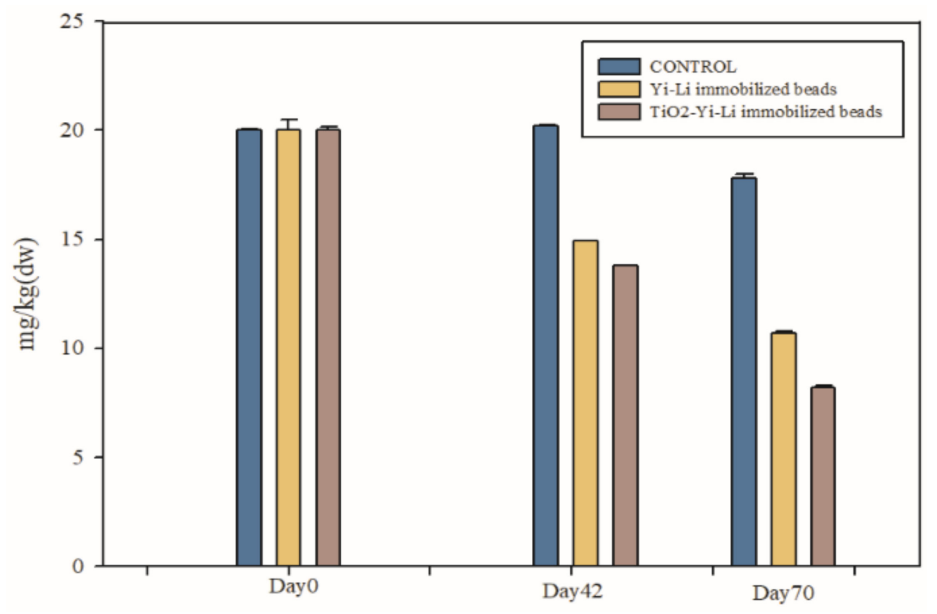

Figure 6. BDE-209 degradation by $\mathrm{TiO}_{2}-\mathrm{Yi}$-Li immobilized chitosan beads and $\mathrm{Yi}$-Li immobilized chitosan beads.

3.2.2. Analysis of the Bacterial Number Present during the $\mathrm{TiO}_{2}-\mathrm{BDE} 209$ Degradation Microorganisms

Changes in bacterial populations over time were estimated by plating samples on R2A agar and BDE-209-MSA agar containing BDE-209 as a sole carbon source; samples obtained during the UV irradiation-biodegradation process with $\mathrm{TiO}_{2}-\mathrm{Yi}-\mathrm{Li}$ immobilized chitosan beads and with Yi-Li immobilized chitosan beads during the biodegradation process are compared in Figure 7.

(a)

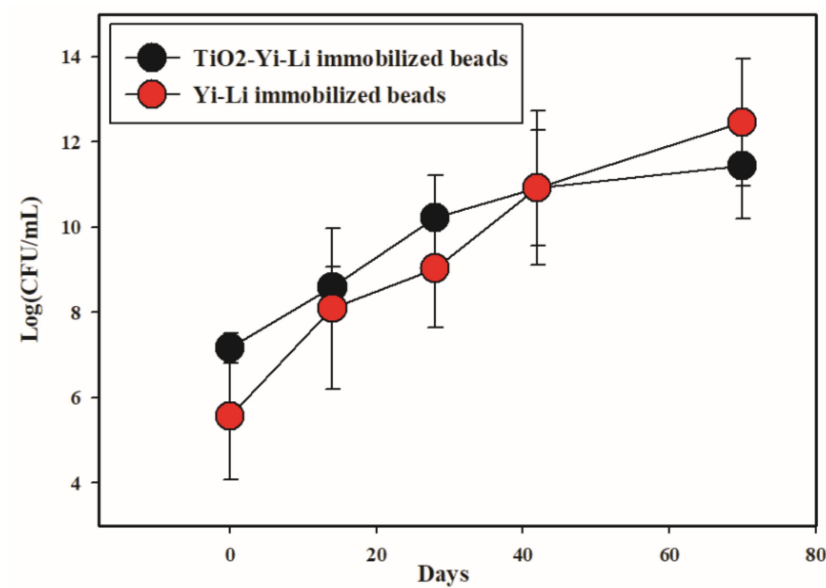

(b)

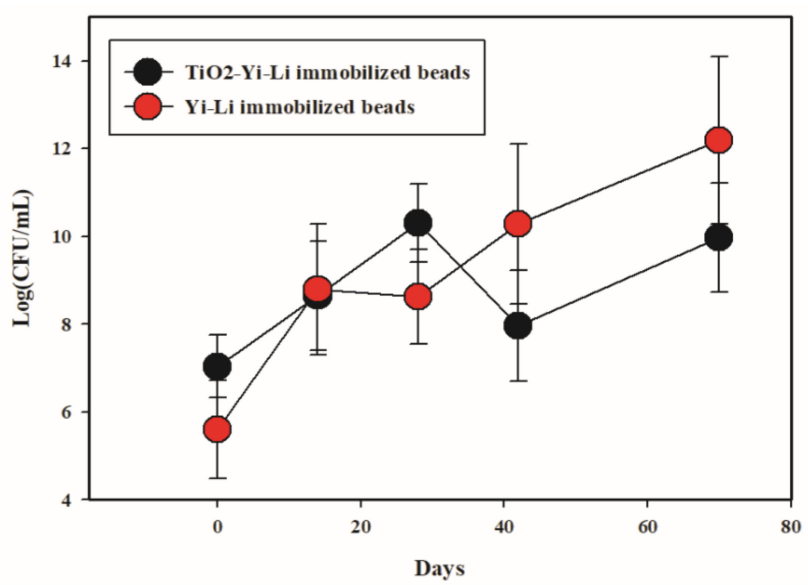

Figure 7. The number of bacteria present during BDE-209 degradation: (a) heterotrophic bacteria; (b) BDE-209-degrading bacteria. The $\mathrm{Y}$ axis is a log scale.

The average number of bacteria present increased over time during the biodegradation process with Yi-Li immobilized chitosan beads. The total number of bacteria present growing on R2A agar increased from $3.67 \times 10^{5} \mathrm{CFU} / \mathrm{g}$ on D0 to a high of $2.88 \times 10^{13} \mathrm{CFU} / \mathrm{g}$ on D70. A similar trend was found for the number of bacteria present growing on BDE209-MSA-agar, which increased from $4 \times 10^{5} \mathrm{CFU} / \mathrm{g}$ on D0 to $1.56 \times 10^{13} \mathrm{CFU} / \mathrm{g}$ on D70. Furthermore, the average number of bacteria present also increased during the UV irradiation-biodegradation process with $\mathrm{TiO}_{2}-\mathrm{Yi}$ - $\mathrm{Li}$ immobilized chitosan beads. The total number of bacteria growth on R2A agar present during the UV irradiation-biodegradation process with $\mathrm{TiO}_{2}-\mathrm{Yi}$ - $\mathrm{Li}$ immobilized chitosan beads increased from $1.45 \times 10^{7} \mathrm{CFU} / \mathrm{g}$ on D0 to $2.72 \times 10^{12} \mathrm{CFU} / \mathrm{g}$ on D70. The number of bacteria present growing on BDE-209-MSB agar increased from $1.08 \times 10^{7} \mathrm{CFU} / \mathrm{g}$ on D0 to $9.27 \times 10^{10} \mathrm{CFU} / \mathrm{g}$ on D70. However, the number of bacteria present showed a decrease to $9.26 \times 10^{9} \mathrm{CFU} / \mathrm{mL}$ on D42. From this 
it is inferred that the number of Yi-Li bacteria present was affected by the continuous UV irradiation present in the latter system, although it was able to recover.

\subsubsection{Bacterial Community Analysis of the BDE-209-Degrading Microorganisms}

Figure 8 shows the "top 10" genus-level analysis of the bacterial communities present in the clay slurry microcosm on D0 and the 56th day (D56) during the BDE-209 degradation experiment. On D0, the dominant bacteria were Pseudomonas spp. and Acinetobacter spp. for both bead systems.

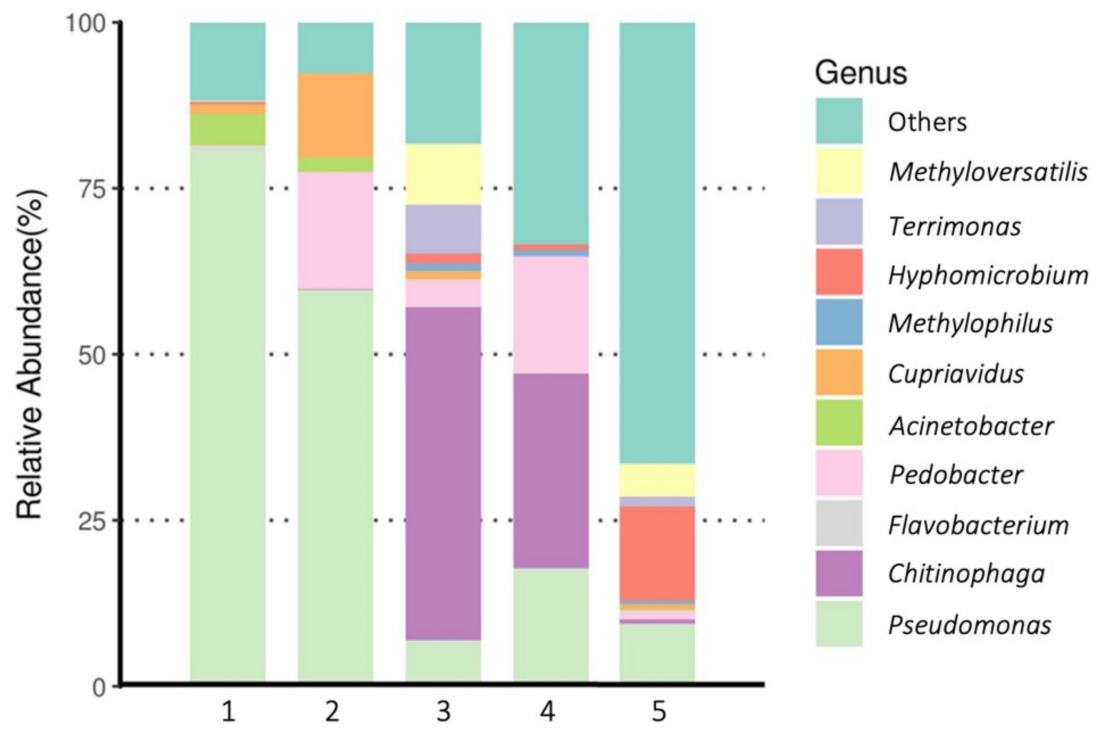

Figure 8. Dominant genus-level microorganisms presented in the BDE-209 contained a clay-slurry system during the degradation by the $\mathrm{TiO}_{2}-\mathrm{Yi}-\mathrm{Li}$ immobilized chitosan beads coupled with UVA irradiation. Value on the $\mathrm{X}$ axis is defined as 1: D0, $\mathrm{TiO}_{2}-\mathrm{Yi}-\mathrm{Li}$ immobilized beads; 2: D0, Yi$\mathrm{Li}$ immobilized beads; 3: $\mathrm{D} 56, \mathrm{TiO}_{2}$-Yi-Li immobilized beads; 4: D56, Yi-Li immobilized beads; 5: Inoculum of Yi-Li bacterial mixed cultures (control).

On D56, when the community structure of the $\mathrm{TiO}_{2}-\mathrm{Yi}-\mathrm{Li}$ immobilized chitosan beads with UVA group system was explored, the dominant bacteria were now Chitinophaga spp. (50.17\%), Methyloversatilis spp. (9.11\%), Terrimonas spp. (7.41\%) and Pseudomonas spp. (6.96\%). This should be compared with the D56 of the Yi-Li immobilized chitosan beads with UVA system, where the dominant bacteria were Chitinophaga spp. (29.33\%), Pseudomonas spp. (17.76\%), Pedobacter spp. (17.50\%), Cephaloticoccus spp. (3.46\%) and Isosphaera spp. (3.40\%).

\section{Discussions}

\subsection{Advantages of $\mathrm{TiO}_{2}-\mathrm{Yi}$-Li Immobilized Chitosan Beads When Carrying out BDE-209 Degradation}

The biodegradation kinetics of BDE-209 in a clay/water system can be described as firstorder. The first-order rate constants ( $\mathrm{k}$ ) for BDE-209 degradation containing $\mathrm{TiO}_{2}-\mathrm{Yi}-\mathrm{Li} \mathrm{im}$ mobilized chitosan beads in the present study decreased in the order $\mathrm{TiO}_{2}-\mathrm{Yi}$-Li immobilized chitosan beads $(\mathrm{k}=0.166,1 /$ day $)>$ Yi-Li immobilized chitosan beads $(\mathrm{k}=0.132,1 /$ day $)$. Previously, the rates of BDE-209 degradation in a clay slurry system have been ranked for an aerobic novel bioslurry reactor in the order: coupled UV photolysis-biodegradation $(\mathrm{k}=0.0131$, $1 /$ day $)>\operatorname{UV}$ photolysis alone $(\mathrm{k}=0.011,1 /$ day $)>$ biodegradation alone $(\mathrm{k}=0.01,1 /$ day) [10]. The slowest rate constant for BDE-209 degradation was found to be 0.00541 /day when the Yi-Li bacterial-mixed culture was added, and the degradation carried out in the dark [23].

Biodegradation is not the only mechanism to remove BDE-209 in a clay/water system between adding $\mathrm{TiO}_{2}$-Yi-Li immobilized beads and Yi-Li-immobilized beads. The $\mathrm{TiO}_{2}-\mathrm{Yi}$ - Li immobilized beads contain, at day 0 , more viable CFUs as compared to Yi-Li- 
immobilized beads (at least two orders of magnitude). However, bacterial number of $\mathrm{TiO}_{2}$-Yi-Li immobilized beads is restricted by both photolysis and photocatalysis after $28 \mathrm{~h}$ during BDE-209 degradation. It is inferred that the better degradation performances of BDE-209 by adding $\mathrm{TiO}_{2}-\mathrm{Yi}$ - $\mathrm{Li}$ immobilized beads is measured, considering the synergistic effect of $\mathrm{TiO}_{2}$ particles and the metabolic potential of bacteria entrapped in the beads.

There are some advantages to the use of immobilized bacterial cells for soil bioremediation, biodegradation, and biotransformation of ECs in wastewater treatment plants. First, compared with clay slurries systems utilizing suspended microorganisms, immobilized bacterial beads offer good biocompatibility, good bioavailability, a low cost and ease of preparation. Secondly, the suspended $\mathrm{TiO}_{2}$ powders provide a significant level of photocatalytic activity compared to other immobilized cells techniques [31]. The use of $\mathrm{TiO}_{2}$ nanoparticles not enclosed in beads is likely to result in widespread distribution of these nanoparticles into the environment, and this could become a significant secondary contamination problem. Finally, $\mathrm{TiO}_{2}-\mathrm{Yi}-\mathrm{Li}$ immobilized chitosan beads are able to entrap both suspended nano- $\mathrm{TiO}_{2}$ particles and significant numbers of BDE-209 biodegrading bacteria with a higher metabolic activity; both of which can carry out excellent removal of BDE-209 in a clay slurry system. Multiple mechanisms, namely UV photolysis, photocatalysis, and biodegradation, are expected to occur at the same time during the $\mathrm{TiO}_{2}-\mathrm{Yi}$ - $\mathrm{Li}$ immobilized chitosan bead remediation process. The $\mathrm{TiO}_{2}$ immobilized chitosan beads technique would seem to be one of the best practical methods for remediating ECs ex-situ without causing significant environmental contamination.

4.2. Evaluation of the Optimal Immobilization Matrix for $\mathrm{TiO}_{2}$-Microbes Immobilized Beads to Be Used in an Aerobic Clay Slurry Microcosm

Alginate and chitosan have been shown to have good compatibility when used an immobilization matrix [32]. Since the entrapment immobilization process results in an intermediate binding force and a high stability, it seems likely that the microbes will be able to survive during the immobilization process. Immobilization in alginate beads has been reported to be a gentler and better method of microbial immobilization [32]. However, the mechanical strength of alginate beads is relatively weaker than that of chitosan beads [33]. The $\mathrm{TiO}_{2}$ immobilized chitosan beads preparation protocol was developed and modified on the basis of several studies [26-28]. In order to immobilize $\mathrm{TiO}_{2}$ particles and microbes together in beads and use these to treat ECs in a clay slurry system, the beads need to be relatively strong in terms of mechanical strength; this is because they must maintain their shape in a stirred clay slurry system. Additionally, the immobilized beads need enough mechanical strength to allow them to be potentially used in aerobic bioslurry reactors for ex-situ bioremediation when future applications are developed [34]. Thus, chitosan immobilization with bead-surface reinforcement by glutaraldehyde treatment was selected as the immobilization method to be used in this study.

$\mathrm{MB}$ was selected as the model organic contaminant to evaluate the degradation performance of the $\mathrm{TiO}_{2}$ immobilized chitosan beads in this study. Figure 9 shows the $\mathrm{TiO}_{2}$ immobilized chitosan beads retain their photocatalytic activity in the presence of UVA irradiation throughout the experiment.

The percentage of MB degradation (\%) under UV irradiation became lower and followed the order: $0.1 \% \mathrm{TiO}_{2}$ immobilized chitosan beads $(89.11 \%)>0.05 \% \mathrm{TiO}_{2} \mathrm{immobilized}$ chitosan beads $(70.02 \%)>0.01 \% \mathrm{TiO}_{2}$ immobilized chitosan beads $(19.08 \%)$. The pseudo first-order-rate constants were calculated to be: $0.1 \% \mathrm{TiO}_{2}$ immobilized chitosan beads $(0.65,1 / \mathrm{h})>0.05 \% \mathrm{TiO}_{2}$ immobilized chitosan beads $(0.51,1 / \mathrm{h})>0.01 \% \mathrm{TiO}_{2} \mathrm{immobilized}$ chitosan beads $(0.13,1 / \mathrm{h})$. Degradation of MB did not occur under the five control conditions, which are variants 1-5 listed in Table 2. These results indicated there was no absorption of $\mathrm{MB}$ onto the $\mathrm{TiO}_{2}$ immobilized chitosan beads over $24 \mathrm{~h}$, and the degradation was brought about by $\mathrm{TiO}_{2}$ photocatalysis. In addition, Figure S3 shows the photograph of $\mathrm{TiO}_{2}$ immobilized chitosan beads before and after $\mathrm{MB}$ degradation. Beads have retained their shape and have shown good stability and mechanical strength while in the 
stirring system. They maintained their shape and diameter throughout the photocatalytic degradation experiment.

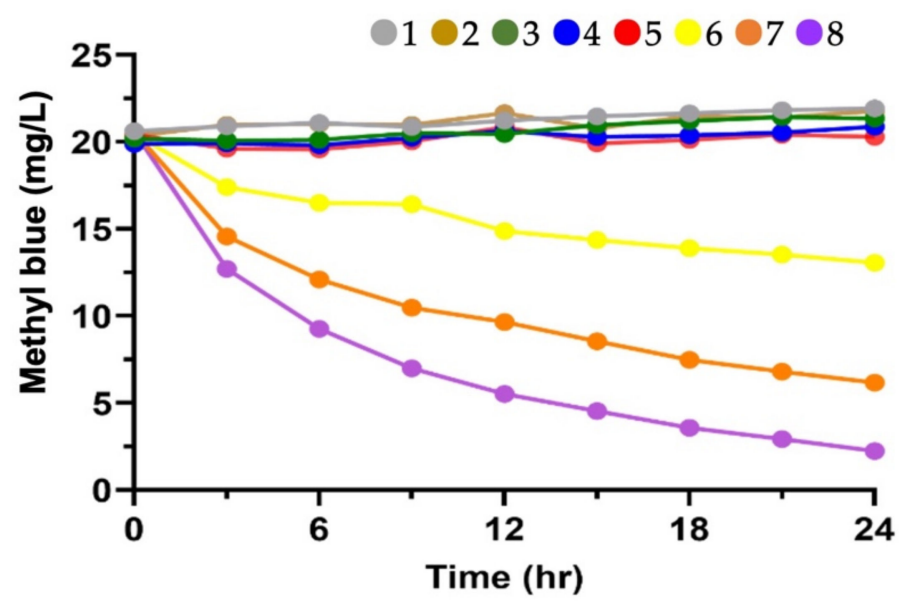

Figure 9. Degradation of methyl blue by $\mathrm{TiO}_{2}$ immobilized chitosan beads. No. of legends $(\bullet)$ is defined as variants of Table 4 . The average value is presented here without error bars due to the very small variations in the values over the three replicates.

\subsection{The Bacterial Communities Involved in the BDE-209 Biodegradation in an Aerobic Clay Slurry Microcosm}

Many bacteria identified in this study are capable of biodegrading BDE-209, as well as other PBDE congeners and aromatic POPs. Both Pseudomonas spp. and Acinetobacter spp. have been reported to have the ability to degrade BDE-209 and are often found in PBDEs contaminated natural habitats [6,35]. The percentage of Methyloversatilis spp. and Terrimonas spp. was significantly higher in the $\mathrm{TiO}_{2}-\mathrm{Yi}-\mathrm{Li}$ immobilized chitosan beads with UVA system compared to the system lacking $\mathrm{TiO}_{2}$. These two bacteria have been reported to be UV-resistant bacteria and have also been shown to have the ability to survive exposure to $\mathrm{TiO}_{2}[6,36]$. In addition, the ability of Methyloversatilis spp. to degrade benzene has been reported, which is suggestive of the ability to break down BDE-209 [37]. Bacterial enrichment cultures that included Cephaloticoccus spp. have been used to biotransform mycotoxin deoxynivalenol into less toxic metabolites [38]. Chitinophaga spp. were present in significant numbers on the D56 in both groups. This might be attributable to the ability of Chitinophaga spp. to produce extracellular chitinase; this will degrade the chitin that forms the main material of the immobilized beads. Thus, Chitinophaga spp. would seem to be utilizing chitosan as a carbon resource rather than BDE-209, and as a result have become the dominant bacteria by D56 [39]. Isosphaera spp. of aerobic Planctomycetes on the D56 also are chitinolytic microorganisms that are present in wetland soils; they are known to be able to biodegrade the complex heteropolysaccharides present in EPS and cell walls; this seems to be their main ecological function [40].

Photocatalytic reactions create an environment in which some bacterial species do not thrive; this is due to conditions where there are high level of free radicals such as $\mathrm{OH}$. that have been created by the $\mathrm{TiO}_{2}$-UVA irradiation reaction. For example, the percentage of Pseudomonas spp. present can be seen to be a significant difference in both systems, namely $17.76 \%$ in the $\mathrm{Yi}$-Li immobilized chitosan beads that lack $\mathrm{TiO}_{2}$ in their UVA system compared to a lower level of $6.69 \%$ in $\mathrm{TiO}_{2}$-Yi-Li immobilized chitosan beads, both on D56. On the other hand, some other bacterial species are able to survive and then begin to play important roles in the $\mathrm{TiO}_{2}$-Yi-Li immobilized chitosan beads with UVA system, compared with the Yi-Li immobilized chitosan beads with UVA system, again both on D56. Chitinophaga spp. have been reported to be involved in a combination of non-thermal plasma and biological processes [41]. Non-thermal plasma involves in the acceleration of primary electrons by collision with background molecules, and this then produces highly reactive free radicals $(\mathrm{OH}$ and $\mathrm{O} \cdot)$. Pedobacter spp., when exposed to a cold temperature 
and high UV radiation, have been shown to turn on an important antioxidant system and produce a variety of pigments that belong to the carotenoids group; these are capable of preventing oxidative damage [42].

\section{Conclusions}

This study describes the development and characterization of a novel immobilization technique whereby $\mathrm{TiO}_{2}$ and a BDE-209-degrading bacterial mixed culture are trapped in chitosan beads. It was found that this system is able to effectively remove BDE-209 in a clay slurry system, while at the same time decreasing the risk of secondary contamination of the environment with $\mathrm{TiO}_{2}$. The $\mathrm{TiO}_{2}-\mathrm{Yi}$ - $\mathrm{Li}$ immobilized chitosan beads retained both photocatalytic and biodegradation activity after the various steps needed for immobilization were carried out. Importantly, the Yi-Li microbes added to the beads ability to biodegrade an EC and, furthermore, this mixed culture was able to tolerate long-term UVA irradiation, as well as exposure to the high levels of free radical generated by the $\mathrm{TiO}_{2}-\mathrm{UV}$ photocatalytic reaction and the UV irradiation itself. In this system, there are three degradation mechanisms in action-microbial bioremediation, photocatalysis and UV degradation-and all of these are likely to have contributed to the breakdown of the high-brominated PBDEs present in the system; this will have produced low-brominated PBDEs congeners. Thus, the $\mathrm{TiO}_{2}-\mathrm{Yi}-\mathrm{Li}$ immobilized chitosan beads are an approach with strong potential for treating ECs contaminated soils. Based on this immobilization procedure, further investigations are needed to increase the mechanical strength of immobilized beads. Such an improvement would mean that the beads could be reused, which would make the treatment of environmental pollutants even more cost effective. Furthermore, the bacteria that are able to tolerate and thrive under the multiple environmental stresses could then be isolated and used to create a new culture that can be added to a new batch of beads. Such a culture, when combined with this new immobilization technique, should have a significantly higher BDE-209 removal efficiency than the Yi-Li culture used here.

Supplementary Materials: The following are available online at https: / www.mdpi.com/article/ 10.3390 / microorganisms10020402/s1, Figure S1. Schematic of the $\mathrm{TiO}_{2}$-immobilization procedure., Figure S2. The viability of the Da-An bacteria in the various chemicals used in the immobilization procedure. Value 1-6 on the $\mathrm{X}$ axis is defined as each step of Table 3, including the various chemicals used during the immobilization procedure. Step: 1: Control- $0.85 \% \mathrm{NaCl}$; step 2: $1 \%$ acetic acid; step 3: $0.1 \% \mathrm{TiO}_{2}$ in $1 \%$ acetic acid; step 4: $0.05 \% \mathrm{TiO}_{2}$ in $1 \%$ acetic acid; step 5: $1 \%$ sodium triphosphate; step 6: $0.25 \%$ glutaraldehyde. Figure S3. Photographs of the $\mathrm{TiO}_{2}$ immobilized chitosan beads. (a) Before use in the dye degradation experiment. (b) After use in the dye degradation experiment.

Author Contributions: Conceptualization, Y.-T.C.; methodology, J.-S.H., T.-Y.Y. and D.-J.W.; writingoriginal draft preparation, J.-S.H. and Y.-T.C.; writing-review and editing, Y.-T.C. and W.-N.J.; supervision, Y.-T.C.; project administration, Y.-T.C.; funding acquisition, Y.-T.C. All authors have read and agreed to the published version of the manuscript.

Funding: This research was funded by project grants from Taiwan MOST; grant number MOST 108-2918-I-031-001 and MOST110-2221-E-031-002.

Acknowledgments: The authors would like to thank Kuo, Yu-Lun at BIOTOOLS Co., Ltd. in Taiwan for their kind support with the NGS data analysis.

Conflicts of Interest: The authors declare no conflict of interests regarding the publication of this paper.

\section{References}

1. Zouboulis, A.I.; Moussas, P.A. Groundwater and soil pollution: Bioremediation. In Encyclopedia of Environmental Health; Nriagu, J.O., Ed.; Elsevier: Amsterdam, The Netherlands, 2011; pp. 1037-1044.

2. Drage, D.; Mueller, J.; Birch, G.; Eaglesham, G.; Hearn, L.; Harrad, S. Historical trends of PBDEs and HBCDs in sediment cores from Sydney estuary, Australia. Sci. Total Environ. 2015, 512-513, 177-184. [CrossRef] [PubMed]

3. Wu, Z.; Han, W.; Yang, X.; Li, Y.; Wang, Y. The occurrence of polybrominated diphenyl ether (PBDE) contamination in soil, water/sediment, and air. Environ. Sci. Pollut. Res. 2019, 26, 23219-23241. [CrossRef] [PubMed] 
4. $\quad$ Lee, E.; Kim, T.H.; Choi, J.S.; Nabanata, P.; Kim, N.Y.; Ahn, M.Y.; Jung, K.K.; Kang, I.H.; Kim, T.S.; Kwack, S.J.; et al. Evaluation of liver and thyroid toxicity in Sprague-Dawley rats after exposure to polybrominated diphenyl ether BDE-209. J. Toxicol. Sci. 2010, 35, 535-545. [CrossRef] [PubMed]

5. Schecter, A.; Pavuk, M.; Päpke, O.; Ryan, J.J.; Birnbaum, L.; Rosen, R. Polybrominated diphenyl ethers (PBDEs) in U.S. mothers milk. Environ. Health Perspect. 2003, 111, 1723-1729. [CrossRef] [PubMed]

6. Chang, Y.-T.; Chou, H.-L.; Li, H.; Boyd, S. Variation of Microbial Communities in Aquatic Sediments under Long-Term Exposure to Decabromodiphenyl Ether and UVA Irradiation. Sustainability 2019, 11, 3773. [CrossRef]

7. Stiborova, H.; Vrkoslavova, J.; Lovecka, P.; Pulkrabova, J.; Hradkova, P.; Hajslova, J.; Demnerova, K. Aerobic biodegradation of selected polybrominated diphenyl ethers (PBDEs) in wastewater sewage sludge. Chemosphere 2015, 118, 315-321. [CrossRef] [PubMed]

8. Wu, Z.; Xie, M.; Li, Y.; Gao, G.; Bartlam, M.; Wang, Y. Biodegradation of decabromodiphenyl ether (BDE 209) by a newly isolated bacterium from an e-waste recycling area. $A M B$ Express 2018, 8, 27. [CrossRef]

9. Demirtepe, H.; Imamoglu, I. Degradation of decabromodiphenyl ether (BDE-209) in microcosms mimicking sediment environment subjected to comparative bioremediation strategies. J. Environ. Manag. 2019, 233, 120-130. [CrossRef]

10. Chang, Y.-T.; Chen, H.-C.; Chou, H.-L.; Li, H.; Boyd, S.A. A coupled UV photolysis-biodegradation process for the treatment of decabrominated diphenyl ethers in an aerobic novel bioslurry reactor. Environ. Sci. Pollut. Res. 2021, 28, 6078-6089. [CrossRef]

11. Zhang, Z.; Wang, C.; Li, J.; Wang, B.; Wu, J.; Jiang, Y.; Sun, H. Enhanced bioremediation of soil from Tianjin, China, contaminated with polybrominated diethyl ethers. Environ. Sci. Pollut. Res. 2014, 21, 14037-14046. [CrossRef]

12. Zhang, B.; Guo, Y.; Huo, J.; Xie, H.; Xu, C.; Liang, S. Combining chemical oxidation and bioremediation for petroleum polluted soil remediation by BC-nZVI activated persulfate. Chem. Eng. J. 2020, 382, 123055. [CrossRef]

13. Chow, K.L.; Man, Y.B.; Zheng, J.S.; Liang, Y.; Tam, N.F.-Y.; Wong, M.H. Characterizing the optimal operation of photocatalytic degradation of BDE-209 by nano-sized $\mathrm{TiO}_{2}$. J. Environ. Sci. 2012, 24, 1670-1678. [CrossRef]

14. Dong, H.; Zeng, G.; Tang, L.; Fan, C.; Zhang, C.; He, X.; He, Y. An overview on limitations of TiO 2 -based particles for photocatalytic degradation of organic pollutants and the corresponding countermeasures. Water Res. 2015, 79, 128-146. [CrossRef]

15. Kagaya, S.; Shimizu, K.; Arai, R.; Hasegawa, K. Separation of titanium dioxide photocatalyst in its aqueous suspensions by coagulation with basic aluminium chloride. Water Res. 1999, 33, 1753-1755. [CrossRef]

16. Rincón, G.J.; La Motta, E.J. A fluidized-bed reactor for the photocatalytic mineralization of phenol on $\mathrm{TiO}_{2}$-coated silica gel Heliyon 2019, 5, e01966. [CrossRef]

17. Lee, C.-G.; Javed, H.; Zhang, D.; Kim, J.-H.; Westerhoff, P.; Li, Q.; Alvarez, P.J.J. Porous Electrospun Fibers Embedding TiO 2 for Adsorption and Photocatalytic Degradation of Water Pollutants. Environ. Sci. Technol. 2018, 52, 4285-4293. [CrossRef]

18. Lei, P.; Wang, F.; Gao, X.; Ding, Y.; Zhang, S.; Zhao, J.; Liu, S.; Yang, M. Immobilization of TiO ${ }_{2}$ nanoparticles in polymeric substrates by chemical bonding for multi-cycle photodegradation of organic pollutants. J. Hazard. Mater. 2012, 227-228, 185-194. [CrossRef]

19. Delnavaz, M.; Ayati, B.; Ganjidoust, H.; Sanjabi, S. Application of concrete surfaces as novel substrate for immobilization of TiO 2 nano powder in photocatalytic treatment of phenolic water. J. Environ. Health Sci. Eng. 2015, 13, 58. [CrossRef]

20. Cunha, D.L.; Kuznetsov, A.; Achete, C.A.; Machado, A.; Marques, M. Immobilized $\mathrm{TiO}_{2}$ on glass spheres applied to heterogeneous photocatalysis: Photoactivity, leaching and regeneration process. PeerJ 2018, 6, e4464. [CrossRef]

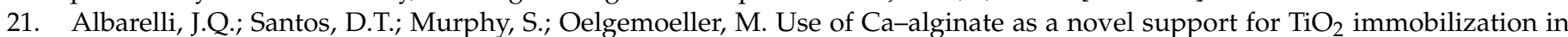
methylene blue decolorisation. Water Sci. Technol. 2009, 60, 1081-1087. [CrossRef]

22. Park, M.-R.; Kim, D.-J.; Choi, J.-W.; Lim, D.-S. Influence of Immobilization of Bacterial Cells and $\mathrm{TiO}_{2}$ on Phenol Degradation. Water Air Soil Pollut. 2013, 224, 1473. [CrossRef]

23. Chou, H.L.; Hwa, M.Y.; Lee, Y.C.; Chang, Y.J.; Chang, Y.T. Microbial degradation of decabromodiphenyl ether (DBDE) in soil slurry microcosms. Environ. Sci. Pollut. Res. 2016, 23, 5255-5267. [CrossRef]

24. Kubacka, A.; Suarez-Diez, M.; Rojo, D.; Bargiela, R.; Ciordia, S.; Zapico, I.; Albar, J.P.; Barbas, C.; Dos Santos, V.A.P.M.; Fernández-García, M.; et al. Understanding the antimicrobial mechanism of $\mathrm{TiO}_{2}$-based nanocomposite films in a pathogenic bacterium. Sci. Rep. 2015, 4, 4134. [CrossRef]

25. Klindworth, A.; Pruesse, E.; Schweer, T.; Peplies, J.; Quast, C.; Horn, M.; Glockner, F.O. Evaluation of general 16S ribosomal RNA gene PCR primers for classical and next-generation sequencing-based diversity studies. Nucleic Acids Res. 2013, 41, e1. [CrossRef]

26. Çetinus, Ş.A.; Öztop, H.N. Immobilization of catalase into chemically crosslinked chitosan beads. Enzym. Microb. Technol. 2003, 32, 889-894. [CrossRef]

27. Chen, Y.-M.; Lin, T.-F.; Huang, C.; Lin, J.-C.; Hsieh, F.-M. Degradation of phenol and TCE using suspended and chitosan-bead immobilized Pseudomonas putida. J. Hazard. Mater. 2007, 148, 660-670. [CrossRef]

28. Huang, K.S.; Grumezescu, A.M.; Chang, C.Y.; Yang, C.H.; Wang, C.Y. Immobilization and stabilization of $\mathrm{TiO}_{2}$ nanoparticles in alkaline-solidificated chitosan spheres without cross-linking agent. Int. J. Latest Sci. Res. Technol. 2014, 3, 74-178.

29. Yilmaz Atay, H. Antibacterial activity of chitosan-based systems. In Functional Chitosan: Drug Delivery and Biomedical Applications; Jana, S., Ed.; Springer: Singapore, 2020; pp. 457-489.

30. Sehmi, S.K.; Allan, E.; MacRobert, A.J.; Parkin, I. The bactericidal activity of glutaraldehyde-impregnated polyurethane. MicrobiologyOpen 2016, 5, 891-897. [CrossRef] 
31. Rao, K.S.; Subrahmanyam, M.; Boule, P. Immobilized $\mathrm{TiO}_{2}$ photocatalyst during long-term use: Decrease of its activity. Appl. Catal. B Environ. 2004, 49, 239-249. [CrossRef]

32. Nedovic, V.; Willaert, R. Fundamentals of Cell Immobilization Biotechnology, 1st ed.; Springer: Dordrecht, The Netherlands, 2004.

33. Gåserød, O.; Sannes, A.; Skjåk-Bræk, G. Microcapsules of alginate-chitosan. II. A study of capsule stability and permeability. Biomaterials 1999, 20,773-783. [CrossRef]

34. Yu, C.-C.; Chang, T.-C.; Liao, C.-S.; Chang, Y.-T. A Comparison of the Microbial Community and Functional Genes Present in Free-Living and Soil Particle-Attached Bacteria from an Aerobic Bioslurry Reactor Treating High-Molecular-Weight PAHs Sustainability 2019, 11, 1088. [CrossRef]

35. Wang, L.; Li, Y.; Zhang, W.; Niu, L.; Du, J.; Cai, W.; Wang, J. Isolation and characterization of two novel psychrotrophic decabromodiphenyl ether-degrading bacteria from river sediments. Environ. Sci. Pollut. Res. 2016, 23, 10371-10381. [CrossRef] [PubMed]

36. Li, K.; Qian, J.; Wang, P.; Wang, C.; Lu, B.; Jin, W.; He, X.; Tang, S.; Zhang, C.; Gao, P. Responses of freshwater biofilm formation processes (from colonization to maturity) to anatase and rutile $\mathrm{TiO}_{2}$ nanoparticles: Effects of nanoparticles aging and transformation. Water Res. 2020, 182, 115953. [CrossRef] [PubMed]

37. Cai, T.; Qian, L.; Cai, S.; Chen, L. Biodegradation of Benazolin-Ethyl by Strain Methyloversatilis sp. cd-1 Isolated from Activated Sludge. Curr. Microbiol. 2010, 62, 570-577. [CrossRef]

38. Vanhoutte, I.; De Tender, C.; Demeyere, K.; Abdallah, M.; Ommeslag, S.; Vermeir, P.; Saeger, S.; Debode, J.; Meyer, E.; Croubels, S.; et al. Bacterial Enrichment Cultures Biotransform the Mycotoxin Deoxynivalenol into a Novel Metabolite Toxic to Plant and Porcine Cells. Toxins 2021, 13, 552. [CrossRef]

39. Sharma, S.; Kumar, S.; Khajuria, A.; Ohri, P.; Kaur, R.; Kaur, R. Biocontrol potential of chitinases produced by newly isolated Chitinophaga sp. S167. World J. Microbiol. Biotechnol. 2020, 36, 90. [CrossRef]

40. Wieczorek, A.S.; Schmidt, O.; Chatzinotas, A.; Von Bergen, M.; Gorissen, A.; Kolb, S. Ecological Functions of Agricultural Soil Bacteria and Microeukaryotes in Chitin Degradation: A Case Study. Front. Microbiol. 2019, 10, 1293. [CrossRef]

41. Wei, Z.; Li, H.; He, J.; Ye, Q.; Huang, Q.; Luo, Y. Removal of dimethyl sulfide by the combination of non-thermal plasma and biological process. Bioresour. Technol. 2013, 146, 451-456. [CrossRef]

42. Correa-Llantén, D.N.; Amenábar, M.J.; Blamey, J.M. Antioxidant capacity of novel pigments from an Antarctic bacterium. J. Microbiol. 2012, 50, 374-379. [CrossRef] 